\title{
Bioetika u hrvatskom dnevnom tisku
}

\author{
Ana Volarić Mršić*
}

\begin{abstract}
Sažetak
Među mnogovrsnim temama koje se bave bioetikom i njezinim promicanjem, ovaj rad donosi neke vidove, osobito deontološke prirode novinarstva, kako bi se sustavno i analitički donijela ocjena o profesionalnoj vrijednosti tekstova koje objavljuju naši najčitaniji dnevni listovi. Svakodnevno se u novinama susrećemo s temama koje su tipično bioetičke, a koje može kao takve prepoznati samo budni čitatelj, zato što je bioetika interdisciplinarna, mlada znanost, koju treba i teorijski poznavati, da bi se teme koje ona obuhvaća s tih polazišta obradilo $i$ kao takve predstavilo. Analiza dnevnih novina Večernji list, Jutarnji list, Novi list $i 24$ sata tijekom prvih šest mjeseci 2014. godine pokazala je da je bioetika $u$ hrvatskim novinarskim krugovima još uvijek nepoznata kao znanstveno područje proučavanja, za razliku od sporta, ekonomije, ili politike, koji imaju svoje specijalne izvjestitelje is pravom ih možemo zvati stručnjacima u tim područjima. Možda dolazi vrijeme da se probudi u Hrvatskoj i bioetičko novinarstvo, koje će dati svoj konstruktivni doprinos razvoju suvremenog hrvatskog društva, prema svim deontološkim načelima novinarske struke, koja je i najzaslužnija što je bioetika započela svoj znanstveni uspon do akademskih pozicija u svijetu, krajem prošlog stoljeća. U ovom radu iznose se rezultati kvalitativno-kvantitativne analize svih obrađenih tekstova koji su svojim sadržajem klasificirani kao tekstovi s bioetičkom tematikom, objavljeni od 1. siječnja do 1. srpnja 2014. godine.

Ključne riječi: bioetika, novinarstvo, Večernji list, Jutarnji list, Novi list, 24 sata
\end{abstract}

\section{Uvod}

Suvremeni svijet medija usko je povezan i isprepleten sa svim znanstvenim granama u širem smislu, a novinar je najdirektniji posrednik između znanosti i širokih masa koje svakodnevno koriste informacije različitih profila, pa tako i one znanstvene.

Od mnogovrsnih znanstvenih područja, u kojima po brzini promjena prednjači ona tehnološka, kao što su biomedicina, farmakologija, energetika i s njima povezane srodne grane, mediji svakodnevno pune svoje rubrike nastojeći biti

* Dr. sc. Ana Volarić Mršić, Hrvatski studiji, Sveučilište u Zagrebu (vanjska suradnica). Adresa: Borongajska cesta 83d, 10000 Zagreb, Hrvatska. E-pošta: avmrsic@gmail.com 
prvi i ekskluzivni u plasiranju novih informacija o znanstvenim dostignućima u svim tim područjima. Riječ je o dobroj strani informacijskih struktura, u čijem je sastavu tisak, radio, TV i Internet, zahvaljujući kojima su građani u realnom vremenu obaviješteni o svemu što se događa u svijetu. Sprega između bioetike, kao znanstvene discipline, i svijeta medija, osobito je zanimljiva upravo zato što su novinari zaslužni za njezin munjevit razvoj i uspon do akademskih visina. Sedamdesetih godina prošlog stoljeća u SAD-u, a zatim i u ostalim dijelovima svijeta, novinari su uočili potrebu posredovanja onih informacija koje će obične građane senzibilizirati ili upozoriti na sve ono što bi se moglo opisati kao dvojbeno, ili sumnjivo te na taj način aktivno sudjelovati u oblikovanju javnog mnijenja (De Neen, 2016, 1-6). To su bile one vijesti koje su također i zahvaljujući skandalima otkrivenim u najvišim strukturama američkih javnih ustanova (bolnica) povećali čitanost novina i promovirali bioetiku kao novu znanstvenu disciplinu, neophodnu da moralno bdije nad munjevitim napretkom tehnologije.

Upravo s ciljem procjene kvalitete medijskih napisa koji se odnose na teme iz bioetike, a kojima se bave i najčitaniji hrvatski dnevni listovi svakodnevno, 2014. godine provedeno je istraživanje koje je obuhvaćalo bioetičku tematsku i deontološku analizu dnevnih nvina Večernji list, Jutarnji list, Novi list i 24 sata. To je istraživanje pokazalo da je profesionalna razina navedenih dnevnih listova, kada su u pitanju teme iz bioetike, ispod standarda koje postavlja novinarska dobra praksa i deontologija, a najčešći je razlog tomu upravo nedovoljno poznavanje interdisciplinarnog područja koje obuhvaća bioetika.

\section{Pojam i definiranje bioetike}

Sama riječ bioetika složenica je dviju grčkih riječi: bios ('život') i ethike ('etika') (Reich, 1995, 19). Naziv bioetika pripisuje se američkom znanstveniku Van Rensselaeru Potteru, koji je u svojoj poznatoj knjizi Bioetika: most prema budućnosti (1971.) izložio svoju koncepciju bioetike (Aramini, 2009, 9).

Povijest naziva bioetika prvi se puta spominje u članku W. T. Reicha (1993), a nakon što je taj (interdisciplinarni) znanstvenik iz Kennedy instituta za proučavanje ljudske reprodukcije i bioetiku (Joseph and Rose Kennedy Institute for the Study of Human Reproduction and Bioethics) objavio prvu enciklopediju bioetike Encyclopedia of Bioethics, bioetika je postala priznata kao nova znanost. U toj su enciklopediji sadržane teme i pitanja kojima se bioetika bavi, istaknuta su glavna bioetička pitanja, što je usmjerilo bioetiku u konkretnom znanstvenom smjeru (Aramini, 2009, 9).

Uz već poznatog autora pojma bioetika Van Rensselaera Pottera, u Europi se istim pitanjima bavio teolog Fritz Jahr, koji je još 1927. godine objavio članak pod naslovom Bio-Ethik: eine Umschau über die ethischen Beziehungen des Menschen zu Tier und Pflanze (Muzur i Rinčić, 2011), čime ga se može nazvati ocem europske bioetike.

Od samih početaka postojali su pokušaji formulacije adekvatne definicije bioetike, koja se svrstala među discipline s jednakim akademskim i znanstvenim 
tretmanom, stoga se kao prvo objašnjenje pojma bioetike navodi definicija koju donosi Encyclopedia of Bioethics, koja se koristila više od 20 godina i citirala na svim stranama svijeta kao njezino najpouzdanije određenje, a glasi: »Bioetika je sustavno proučavanje ljudskog ponašanja na području znanosti o životu i zdravstvene skrbi, ako je to ponašanje ispitivano u svjetlu moralnih vrijednosti i načela« (Reich, 1978, 221). Ta definicija mnogima je služila kao temelj za razumijevanje bioetike, no ona je također i od samog početka izazivala stanovite dvojbe i kritike. Ono što se zamjeralo spomenutoj definiciji je riječ „načela“, odnosno „principi“ (Aramini, 2009, 56). Naime, navedena definicija ne razjašnjava dva temeljna pitanja: a) je li bioetika deskriptivna znanost (koja govori o tome kako se ljudi zapravo ponašaju) ili normativna znanost (koja govori o tome kako bi se ljudi trebali ponašati); b) odnose li se moralna načela općenito na etičko istraživanje ili bi trebalo usvojiti načela koja zastupaju pravac bioetike načela (Aramini, 2009, 56). Definicija je u novom izdanju bioetičke enciklopedije (1995) doživjela određene modifikacije: »Bioetika je sustavno proučavanje moralnih dimenzija - uključujući moralnu viziju, odlučivanje, ponašanje i razborito vladanje — znanosti o životu i zdravlju primjenjujući različite etičke metodologije s interdisciplinarnom impostacijom « (Reich, 1995, 247).

Aramini navodi kako proširena definicija bioetička pitanja formulira u svjetlu etike kreposti i time postavlja pitanje kakvim osobama, zapravo, želimo biti. Osim proširenog formalnog objekta, proširen je i materijalni objekt bioetike na društveno ponašanje i političke dimenzije. Još i danas postoje različita stajališta oko definiranja bioetike, pa se stoga nastavlja proces razvijanja pojma bioetike kao takvog (Aramini, 2009, 56).

Smatra se da je ubrzani napredak znanosti i tehnologije (ponajprije u području biomedicinskih znanosti i kliničke medicine), odnosno novostečena moć u stvaranju, manipuliranju, održavanju i okončavanju života povod ubrzanog razvoja bioetike kao znanosti (Zagorac i Jurić, 2008, 601). Zbog napretka u području genetike kao i novih spoznaja i metoda u dijagnosticiranju i liječenju dotad nepoznatih i neizlječivih bolesti, a osobito novi način produžavanja i održavanja života, javila se potreba za većim nadzorom i utjecajem u sustavu liječenja i zdravstvene skrbi. Potterova koncepcija bioetike u vidu zaštite čovječanstva pred munjevitim napretkom biotehnologije, postala je tako temeljni projekt cjelovite znanosti, kakvom ju danas poznajemo pod pojmom bioetike, a koja obuhvaća širok multidisciplinarni pristup očuvanja ne samo ljudske vrste, pod svim antropološkim aspektima, nego i čitavog biosustava i ekosustava (Zagorac i Jurić, 2008).

Tim uvodnim tumačenjem pojma i značenja bioetike definiran je i okvir istraživanja provedenog u najčitanijim tiskanim dnevnicima kod nas tijekom prvog polugodišta 2014. godine. Za raščlambu tema iz područja bioetike korištena je sistematizacija koju je izložio E. Sgreccia (1999) u svojem Priručniku za bioetiku.

Teme iz bioetike podijeljene su u šest cjelina:

1. Ljudska prava: a) prava pacijenata; b) prava djece; c) prava žena; d) prava adolescenata; e) prava starijih osoba; e) prava osoba s invaliditetom. 
2. Bioetika i medicina: a) nove tehnologije u medicini; b) genetski inženjering; c) farmakologija i lijekovi; d) presađivanje organa; e) kloniranje; f) estetska kirurgija; g) potpomognuta oplodnja; h) eutanazija; i) ljudski embrij; j) kontracepcija; k) pokusi na ljudima l) pobačaj.

3. Spolnost i ljudsko rađanje: a) obitelj; b) spolni odgoj; c) plodnost; d) homoseksualnost.

4. Društvo, zdravstvo i kvaliteta života: a) prehrana i GMO; b) ekonomija i zdravstvo; c) zdravlje i prevencija; d) samoubojstvo; e) zaraza virusom humane imunodeficijencije (HIV); f) demografija.

5. Ovisnost: a) droga; b) pušenje; c) alkohol; d) doping.

6. Okoliš; a) zagađenje; b) izvori; c) klima; d) životinje; e) biljke; f) energetika.

\section{Metodologija istraživanja}

S ciljem utvrđivanja toga kako su prezentirane bioetičke teme, a po mogućnosti i bioetika kao takva u hrvatskim odabranim tiskanim dnevnim novinama, poslužili smo se kvalitativno-kvantitativnom analizom sadržaja svih tekstova objavljenih u prvom polugodištu 2014. godine, koji su ulazili u kategoriju bioetičke tematike, prema ranije prikazanoj sistematizaciji u obliku matičnih tablica (matrica).

Polazišne hipoteze istraživanja bile su: a) uočiti možebitnu suradnju između novinara i bioetičara u Hrvatskoj; b) otkriti izlažu li i u kojoj mjeri tekstovi s bioetičkim temama također etičku i moralnu prosudbu iznesenih informacija; c) otkriti koliko je iznesena tema temeljito obrađena (dubinski ili površno); d) otkriti donose li objavljeni tekstovi određenim bioetičkim pitanjima argumente za i protiv određenih etičkih dilema (zahvati, zakoni, postupci itd.).

\section{Selekcija i analiza sadržaja članaka}

Razdoblje analize sadržaja obuhvaćalo je sve novinske tekstove koji su u naslovu i sadržaju obrađivali neku od navedenih bioetičkih tema, objavljenih u dnevnim novinama Večernji list, Jutarnji list, Novi list i 24 sata od 1. siječnja do 30. lipnja 2014. godine. Odabrani tekstovi sortirani su u sljedeće kategorije:

1. ljudska prava (prava pacijenata, prava djece, prava žena, prava mladih, prava starijih osoba, prava osoba s invaliditetom);

2. bioetika i medicina (potpomognuta oplodnja, genetski inženjering, farmakologija i lijekovi, presađivanje organa, kloniranje, estetska kirurgija, pobačaj, eutanazija, ljudski embrij, kontracepcija, pokusi na čovjeku, nove tehnologije u medicini);

3. spolnost i rađanje (obitelj, spolni odgoj, plodnost, homoseksualnost);

4. društvo, zdravstvo i kvaliteta života (hrana i GMO, ekonomija i zdravstvo, zdravlje i prevencija, samoubojstvo, zaraza HIV-om, demografija);

5. ovisnost (droga, pušenje, alkohol, doping); 
6. okoliš (zagađenost, klima, izvori, životinje, biljke, energetika).

Čitanjem odabranih članaka, čiji se sadržaj podudara s jednom od gore navedenih tema i podtema, izvršena je kvalitativna analiza u smislu deontološke, bioetičke i grafičke prosudbe svakoga teksta.

Tekstualna analiza obuhvaćala je sljedeće parametre:

1. vrsta (stalne) rubrike: news, lifestyle, show, crna kronika;

2. veličina naslova: mali, srednji, veliki, vrlo veliki;

3. tekst s potpisom: novinar, znanstvenik, liječnik, student, drugo, bez potpisa, čitatelj;

4. vrsta teksta: vijest, izvješće, komentar, ogled, kolumna, reportaža, razgovor, drugo;

5. položaj teksta: naslovnica, prvih deset stranica, od desete do dvadesete stranice, posljednjih deset stranica;

6. grafička oprema teksta: fotografija, crtež, grafikon, dijagram, više elemenata zajedno;

7. odnos teksta i slike: tekst dominantniji od slike, slika dominantnija od teksta;

8. uloga fotografije: dokumentirati, dočarati, uvjeriti, privući pozornost;

9. broj spominjanja riječi bioetika u tekstu: jednom, dva puta, više od dva puta, ne spominje se;

10. produbljenje i obrada teme: umjereno produbljenje teme, široka obrada teme, površno, nemoguće odrediti;

11. orijentiranost prema publici: široko, usko profesionalnoj publici, prema institucijama, nemoguće odrediti;

12. u tekstu prevladava: kritička nota, ironija, pozitivan stav, negativan stav, neutralan stav;

13. svrha teksta: informirati, educirati, senzacionalizam, kritika, promidžba, nemoguće odrediti;

14. citirani izvori informacija: jedan izvor, dva izvora, tri i više izvora, nema izvora;

15. glavni izvor informacija: agencija, Ministarstvo zdravstva, javne ustanove, privatne ustanove, znanstvenik, političar, novinar, čitatelj, intervjuirane osobe, drugo (neodredivo).

\section{Kriteriji za analitičku ocjenu tekstova}

\subsection{Tema}

Kako bi se odredila glavna tema određenog napisa, potrebno je pojasniti da sadržaj teksta ispod naslova nužno ne odgovara samomu naslovu, ili da sadržaj teksta nije uvijek jednostavno definirati prateći crvenu nit sadržaja istog teksta. Zato se svaki pojedini tekst klasificira s obzirom na temu koja prevladava u čitavom sadržaju. Kao što je poznato, neka bioetička tema dodiruje više pojedinač- 
nih podtema, primjerice tema o obitelji može biti povezana s pitanjem spolnog odgoja, rađanja, kontracepcije ili nasilja. Stoga su tekstovi raspoređeni s obzirom na temu koja je u određenom članku prevladavala i koja je određena naslovom (Contreras, 2005, 7). Primjerice, ako tekst govori o nasilju u nekoj konkretnoj obitelji, konkretno prema ženi, ili djetetu, takav tekst tematski je kategoriziran kao tekst o pravima žene, odnosno djeteta, a nije stavljen u kategoriju — obitelj.

\subsection{Rubrika}

Tekstovi u kojima se govorilo o bioetičkim temama definirani su i s obzirom na to pripadaju li u neku stalnu rubriku ili ne. Taj podatak ukazuje na profil stava uredništva o određenim temama (u ovom slučaju bioetičkih), jer primjerice redovito objavljivanje, tekstova o obitelji u rubrici showbiz, osobito poznatih osoba, ukazuje na to da se obiteljski život prividno vodi samo među „slavnima“, a, recimo pitanje obiteljskog života običnih ljudi, obično se svodi na senzacije oko socijalne pomoći siromašnim obiteljima, pomoći izgradnji njihovih domova. Skoro da i nema tekstova koji bi donosili priče o uspješnim obiteljima, čija djeca postižu vrhunske rezultate i gdje se život odvija uvjetno rečeno - normalno (Volarić-Mršić, 2017, 68).

\subsection{Potpis autora}

Vrijednost i ozbiljnost svakog objavljenog teksta potpisuje autor. Obično je to ime novinara, naziv agencije, čitatelj, ili znanstvenik. U mnogim slučajevima, tekstovi nemaju potpisa, kao ni inicijale autora. Prema toj vrsti podatka novine klasificiramo kao kvalitetne, odnosno manje kvalitetne (Contreras, 2005, 1; Malović, 2007, 101).

\subsection{Novinska vrsta}

Prema novinarskim standardima, tekstovi su razvrstani u sljedeće kategorije: vijest, izviješće, reportaža, razgovor, komentar, prikaz i ostalo (Malović, 2005, 5).

\subsection{Položaj teksta}

Uredništvo određuje položaj i politiku objavljenih tekstova, s obzirom na procjenu o važnosti pojedinih tema. Dakle, u uredničkoj politici nema slučajnosti, pa je i to važan podatak ovoga istraživanja, koje je mjesto dodijeljeno pojedinoj (bioetičkoj) temi (Contreras, 2005, 7; Cantoni i Di Blas, 2006, 109).

\subsection{Grafička oprema teksta}

Kod ocjenjivanja grafičke opreme teksta kriterij je bio definirati je li riječ o fotografiji, crtežu, grafičkom prikazu ili nečem drugom, kao i omjer veličine grafičkog prikaza i tekstualnog opsega. Također posebno se analizirala poruka fotografije koja prati određeni tekst bioetičke tematike, odgovara li fotografija temi i sadržaju objavljenog teksta. Grafički dio informacije vrlo je važan indika- 
tor o tome što se želi reći samim tekstom, kao i nadopuna svega onoga što se u tekstu nije reklo (Gelb, 2008, 3).

\subsection{Spominjanje riječi bioetika}

Cilj je ovoga istraživanja bio saznati što preciznije vrste i kvalitetu zastupljenosti bioetičkih tema u najčitanijem dnevnom tisku, pa je od iznimne važnosti utvrditi poznaju li novinari naziv bioetika, u prilog čemu ide i njegovo korištenje unutar tekstova, bez obzira na to što nije riječ o striktnom bioetičkom događaju ili bioetičkoj vijesti (kao primjerice neki bioetički simpozij gdje ga se ne može izbjeći).

\subsection{Opseg obrade teme}

Za svaku je temu postavljeno pitanje o dubini obrade iste: djelomično ili opsežno, što podrazumijeva iznošenje argumenata za i protiv, komentar stručnjaka i sl., kao i ocjena površne obrade (Bertrand, 2007, 45-55).

\subsection{Stav koji prevladava u tekstu}

Analiza teksta pod vidom ocjene stava koji se iznosi ili koji prevladava u čitavom tekstu, imala je sljedeće moguće ishode: kritički stav, ironija, pozitivan stav, negativan stav, neutralan stav. Kriterij za procjenu tog vrednovanja bio je cjeloviti tekst, uključujući i naslov, iz kojega se već može naslutiti stav koji će dominirati u tekstu (Belsey i Chadwick, 1996, 131-156).

\subsection{Svrha objavljenog teksta}

Analiza je obuhvatila i prosudbu o tome koja je svrha i kojim povodom nastaje određeni tekst, osobito ako se ne podudara s dobrom novinarskom praksom (Bertrand, 2007, 37-40. Malović; Ricchiardi; Vilović, 2007, 59-105). U svrhu ove prosudbe uvršteni su mogući odgovori: informirati, educirati, senzacionalizam, kritika, promidžba i nemoguće odrediti (vidi tablicu u prilogu).

\subsection{Izvori informacije}

Kao mogući broj izvora informacije, koji je proporcionalan i kvaliteti objavljenog napisa (Malović; Ricchiardi; Vilović, 2007, 248), predloženi odgovor sadržan u tabličnoj matrici je: jedan izvor, dva izvora, tri i više izvora; nema istaknutog izvora.

\subsection{Glavni izvor informacije}

Prema izvoru informacije može se procijeniti vjerodostojnost i kvaliteta objavljenih napisa (Contreras, 2005, 5; Bertrand, 2007, 45; Malović; Ricchiardi; Vilović, 2007, 248). Istražujući ne samo frekvenciju pojavljivanja tekstova koji govore ili spominju bioetičke teme (u širem smislu), važno je znati iz kojih su izvora autori objavljenih tekstova crpili glavne i dopunske informacije. Osobito je to važno kada 
se govori o stručnim ili znanstvenim temama, koje bi trebale imati i stručnu utemeljenost i čitatelju ponuditi širi uvid u bit problema o kojem se piše.

Rezultati dobiveni ovom analizom upisani su u pripremljene matrične tablice za svaki dnevni list posebno (Volarić Mršić, 2017, 95-114). Na temelju tih matričnih tablica, izrađene su naknadno tematske i zbirne matrice radi usporedbe dobivenih rezultata za sva četiri dnevna lista paralelno, te i grafički prikazi svake zbirne tablice radi lakše interpretacije dobivenih rezultata.

\section{Rezultati analize tekstova bioetičke tematike}

\subsection{Zastupljenost bioetičkih tema}

Rezultati analize pokazali su da je u prvom polugodištu 2014. godine u četiri dnevna lista objavljeno ukupno 4.676 tekstova čiji se sadržaj dotiče neke od prethodno klasificirane bioetičke teme (Volarić Mršić, 2017, 21). Najviše je bioetičkih tekstova (sve novinarske vrste) objavio Večernji list (1.589), zatim Jutarnji list (1.467), slijedi 24 sata (1.045) te Novi list (575). Te brojke same po sebi ne govore mnogo, osim o frekvenciji bioetičkih tema. Zanimljivo je znati koje su teme prevladavale u ukupnom broju svih objavljenih tekstova bioetičke tematike u svakom pojedinom dnevniku. To je iskazano u tablici ovoga priloga, iz čega je uočljivo da se najviše pozornosti posvetilo temama o ljudskim pravima; 1.367 napisa ili $30 \%$ od ukupnog broja objavljenih tekstova s bioetičkom tematikom. Po broju objavljenih tekstova zatim slijedi tema o okolišu (zagađenje, izvori, klima, životinje, biljke, energetika): ukupno 930 tekstova, što iznosi oko $20 \%$ od ukupnog broja bioetičkih tekstova. Preostalih $50 \%$ tema kojima su se ukupno posvetili naši najčitaniji dnevni listovi pripada onima o društvu, zdravstvu i kvaliteti života, s ukupno 778 objavljenih tekstova, odnosno oko 17\%, zatim teme o ovisnosti (droga, alkohol, pušenje, doping) s ukupno 672 objavljenih napisa ili oko $14 \%$ od ukupnog broja bioetičkih tekstova. Iz područja biomedicine (nove tehnologije u medicini, genetski inženjering, farmakologija i lijekovi, presađivanje organa, kloniranje, estetska kirurgija) objavljen je ukupno 421 tekst, što predstavlja približno $10 \%$ od ukupnog broja objavljenih tekstova iz područja bioetike. U okviru teme o spolnosti i ljudskom rađanju (obitelj, spolni odgoj, plodnost, homoseksualnost) naši su dnevni listovi u razmatranom polugodištu 2014. objavili ukupno 411 tekst, što je oko $9 \%$ u ukupnom udjelu analiziranih tekstova.

Iz prikazanih rezultata o zastupljenosti pojedinih tema, može se zaključiti da je područje ljudskih prava sastavni dio agende setting (McQuail i Windahl, 1993) svih uredništava najčitanijeg dnevnog tiska u Hrvatskoj, odnosno da se pitanju ljudskih prava daje prednost kod kreiranja politike plasiranja informacija u dnevnom tisku. Možemo reći da se među tim pravima najčešće spominje pravo djeteta (36\%). Tema koja se bavi okolišem (zagađenost, izvori, klima, životinje, biljke i energetika) na drugom je mjestu po frekvenciji objavljivanja tekstova u analiziranom dnevnom tisku. Te su teme same po sebi dio svakodnevnih zbivanja u svije- 
tu, a time i u Hrvatskoj. Rezultati tekstualne analize pokazali su da su to ujedno i najprofesionalnije pisani tekstovi hrvatskih novinara za analizirano razdoblje, što se tiče bioetičkog motrišta. Osvrt na udio tekstova koji su obrađivali temu o društvu, zdravstvu i kvaliteti života, s približno $20 \%$, lako je obrazložiti, s obzirom na činjenicu da je većina čitatelja zainteresirana biti redovito informirana o novim zakonima o zdravstvenom osiguranju, prehrani i aktualnostima u vezi s GMO hranom i zakonima koji se o tome pripremaju ili donose, o financijskoj situaciji vezane uz zdravstvo i zdravstveno osiguranje i distribuciju lijekova itd., što sve pripada toj širokoj društveno-bioetičkoj temi. Relativno nizak postotak (10\%) tekstova iz područja medicine (nove tehnologije u zdravstvu, genetski inženjering, farmakologija i lijekovi, presađivanje organa, kloniranje, estetska kirurgija, umjetna oplodnja, eutanazija, ljudski embrij, kontracepcija, pokusi na ljudima, pobačaj) moguće je objasniti usporedbom s podatcima dobivenima jednom drugom analizom tiskanog dnevnika Vjesnik iz 2008. (Volarić Mršić, 2008, 22), koja je pokazala da su tekstovi iz područja medicine i farmakologije zauzimali $30 \%$ sveukupnih tekstova objavljenih u okviru bioetičkih tema, po visokim profesionalnim standardima (broj izvora, potpis autora, dubina obrade teme itd.). Možemo zaključiti da je nepostojanje tog dnevnog lista, što se tiče bioetike, gubitak za hrvatske čitatelje, jer je novo istraživanje iz 2014. pokazalo da se bioetičkim temama prilazi prilično površno i jednosmjerno u dnevnom hrvatskom tisku.

\subsection{Deontološki i kvalitativni kriteriji ocjene objavljenih tekstova o bioetičkim temama}

Ukupan broj objavljenih tekstova iz bioetike (4.676) pokazuje relativno velik broj napisa u kojima se mogla prepoznati neka od istaknutih bioetičkih tema (Volarić Mršić, 2017, 119). No, dublja tekstualna analiza pokazuje da je u tom ukupnom broju tekstova naziv bioetika izričito spomenut svega pet puta. Najvjerojatniji razlog takvoga rezultata je nepoznavanje bioetike kao interdisciplinarne znanosti, koju možemo spominjati u širem kontekstu unutar teme o kojoj se piše. Međutim, bioetika se kao takva u našem dnevnom tisku, skoro i ne spominje. Nadalje, broj tekstova bez ikakvog potpisa autora od ukupnog broja objavljenih tekstova penje se na 1.216, što je $26 \%$ (skoro trećina). Što se tiče izvora informacija korištenih za sastavljanje teksta od ukupnog broja bioetičkih tekstova, bez navođenja izvora pronađeno je 1.678, ili 36\% (više od trećine). Može se postaviti pitanje, koliko može biti vjerodostojan tekst koji nema naveden nijedan izvor informacije (Malović i dr., 2007, 86-88), a ako je riječ o ozbiljnijim temama, navodi se samo jedan izvor, odnosno, poruka ide jednosmjerno. Najčešći su navedeni izvor u analiziranim tekstovima upravo agencije (2.886), što je skoro $62 \%$. Taj podatak ukazuje na to da bez obzira od koje se agencije vijest koristi, nema dodatnog istraživanja i provjeravanja informacija od strane uredništva ili autora teksta, što uvelike smanjuje vjerodostojnost i autentičnost informacije koju se objavljuje.

Detaljna analiza sadržaja tekstova, nadalje, pokazala je da su u svakom dnevniku teme obrađene površno (3.652), što je 78\% tekstova od ukupno analiziranog broja. Premda je cjelovita analiza dokumentirana za svaki dnevni list posebno 
(Volarić Mršić, 2017, 95-122), u ovom prikazu ograničit ćemo se na sveukupne podatke proizišle ovom analizom, zbog ograničenosti prostora za objavljivanje. Rezultat s obzirom na ocjenu „intonacije“ objavljenih tekstova (kritika, pozitivno, negativno, ironija, neutralno) odnosi se na neutralnost tona kojim tekst „odiše" u 2.202 teksta, 47\%, od kojih treba istaknuti ukupno 1.475 Večernjakovih tekstova koji su ocjenjeni kao „neutralni“. Preostali broj od 2.474 tekstova bilo je ili kritično intonirano, pozitivno ili negativno, već prema tome o čemu se u tekstu govorilo.

Procjenjivanje svrhe (cilja) objavljenog teksta pokazuje je da je najzastupljenija ocjena: informirati, u 2.972 teksta, ili 63,5\% ukupno objavljenih tekstova, a tek je rijetko svrha bila senzacionalistička, u svega 717 tekstova, što je $15 \%$ od ukupnog broja analiziranih tekstova. Grafička analiza tekstova pokazala je da su naši najčitaniji dnevni listovi tekstove bioetičke tematike objavili redovito uz neku fotografiju, koja svojim dimenzijama dominira nad tekstom, u 2.621 slučajeva, ili 56\% tekstova. Također najčešća je uloga fotografije dokumentiranje, a tek rijetko uvjeravanje (Volarić Mršić, 2017, 95-122). Ti podatci, između ostaloga, govore u prilog tezi da često nedostaje pravog istraživanja prije objavljivanja nekog bioetičkog teksta, koji je u najčešćem obliku vijesti, 3.223, ili $69 \%$ od svih bioetičkih tekstova objavljenih u prvoj polovici 2014. godine u Večernjem listu, Jutarnjem listu, Novom listu i 24 sata.

\section{Zaključak}

Cjelovita analiza odabranih dnevnih listova Večernji list, Jutarnji list, Novi list i 24 sata s ciljem prepoznavanja tekstova bioetičke tematike od 1. siječnja do 1 . srpnja 2017. godine pokazala je da su početno postavljene hipoteze uglavnom odbačene. a) Možebitna suradnja između novinara i bioetičara za sada ne postoji u Hrvatskoj, prema rezultatima analize sadržaja najčitanijih hrvatskih tiskanih dnevnika. To se dokazuje time, što se bioetika kao pojam spominje svega 5 puta u ukupnom broju od 4.676 (bioetičkih) tekstova, odnosno da se bioetičara, pa čak i šireg stručnjaka koji bi mogao ući u tu kategoriju (etičar, liječnik, svećenik, pravnik) izričito kao izvor informacije navodi svega 3 puta, a političara 49 puta kao sugovornika u davanju informacija vezanih uz tekst (temu) objavljenog napisa. b) Istraživanje je pokazalo da su tekstovi u $78 \%$ slučajeva informirali površno o temama bioetičke tematike o kojima su pisali, što znači da je vrlo mali broj tekstova u kojima se iznosi ikakav etički sud (za ili protiv) neke teme o kojoj se raspravljalo. c) Teme s bioetičkim sadržajem u $78 \%$ obrađene su površno, bez navođenja ikakvog, a osobito više izvora. d) Da bi se iznijeli argumenti za i protiv određenih etičkih dilema, osobito za neke „kontroverzne“ teme poput pobačaja, eutanazije, umjetne oplodnje, spolnog odgoja, obiteljskog zakona itd., treba dati više prostora nego što se pokazalo tijekom ove analize. To znači da kratki oblik vijesti, koji dominira u svim analiziranim dnevnim listovima, premda s velikom učestalošću objavljivanja, u kojem dominira fotografija ili neki drugi oblik grafičke opreme, ne daje prostora iznošenju potvrdnih ili negativnih argumenata za 
cjelovito informiranje o određenoj temi. Tekstova u obliku razgovora (intervjua) objavljeno je u čitavom periodu ukupno 9, što ne može zadovoljiti zahtjev za kompletnom informacijom, bez obzira na stav za ili protiv.

U okviru zaključaka koji proizlaze iz analize s ciljem da se donese ocjena kvalitete tekstova u hrvatskim dnevnicima (Večernji list, Jutarnji list, Novi list i 24 sata) treba spomenuti i činjenicu da je tabloidni oblik dnevnog lista 24 sata pokazao relativno visok stupanj profesionalnosti, osobito po pitanju namjere (cilja) objavljivanja nekog teksta, abila je riječ o informiranju u70\% obrađenih tekstova, senzacionalizam je bio cilj u svega $15 \%$ tekstova. 24 sata je tekstove s bioetičkim temama objavio u $76 \%$ slučajeva među prvih deset stranica, vjerojatno zbog manjeg opsega ukupnog broja stranica samog lista. Večernji list objavljene je tekstove s bioetičkim temama smjestio među prvih deset stranica u $47 \%$ slučajeva, Novi list 45\%, Jutarnji list među prvih deset stranica smjestio je 38\% svojih bioetičkih tekstova (Volarić Mršić, 2017, 95-122). Visok postotak zastupljenosti bioetičkih tema među prvih deset stranica, uključujući i najave na naslovnicama u našim najčitanijim dnevnim listovima govore o tome da su bioetičke teme vrlo aktualne i poželjne za pridobivanje čitatelja. Međutim, detaljnija analiza pokazala je da se te teme ne produbljuju dovoljno, odnosno da je bioetika kao takva još nedovoljno poznata, kako u krugovima koji određuju uređivačku politiku, tako i među samim novinarima, odnosno autorima objavljenih tekstova.

Izazov je za hrvatsko novinarstvo, pored stručne specijalizacije, primjerice iz područja sporta, gospodarstva, politike ili ekologije, uključiti i specijalizaciju iz bioetike, koja zadire svojim područjem proučavanja u sve životne sfere suvremenog čovjeka i društva kao cjeline. Brze promjene koje su karakteristika svih suvremenih demokratskih društava, nadamo se da će zahvatiti s oduševljenjem i hrvatsko novinarstvo, uočavanjem potrebe za produbljivanjem spoznaja o tome što je i čemu bi mogla služiti i bioetika. Rezultat takvog oduševljenja bit će dobro i stručno informirana hrvatska javnost, samim time i formirana, a zasigurno cee, s obzirom na aktualnosti iz svakodnevnog života, svi čitatelji biti i dovoljno zabavljeni.

Tekstovi bioetičke tematike — zbirni rezultati — izdvojene teme

\begin{tabular}{|l|c|c|}
\hline \multicolumn{1}{|c|}{ Tekstovi bioetičke tematike - svi } & $\mathbf{\Sigma = 4 6 7 6}$ & $\mathbf{1 0 0 \%}$ \\
\hline Večernji list & 1589 & 34 \\
\hline Jutarnji list & 1467 & 31 \\
\hline Novi list & 575 & 12 \\
\hline 24 Sata & 1045 & 23 \\
\hline \multicolumn{3}{|c|}{} \\
\hline Ljudska prava & $\mathbf{\Sigma = 2 3 3}$ & $\mathbf{1 0 0 \%}$ \\
\hline Prava pacijenta & 22 & 9 \\
\hline Večernji list & 89 & 38 \\
\hline Jutarnji list & 54 & 23 \\
\hline Novi list & & \\
\hline
\end{tabular}




\begin{tabular}{|c|c|c|}
\hline 24 Sata & 68 & 30 \\
\hline Prava djeteta & $\Sigma=488$ & $100 \%$ \\
\hline Večernji list & 69 & 14 \\
\hline Jutarnji list & 43 & 9 \\
\hline Novi list & 15 & 3 \\
\hline 24 Sata & 361 & 74 \\
\hline Prava žene & $\Sigma=149$ & $100 \%$ \\
\hline Večernji list & 19 & 13 \\
\hline Jutarnji list & 64 & 44 \\
\hline Novi list & 28 & 18 \\
\hline 24 Sata & 38 & 25 \\
\hline Prava starijih osoba & $\Sigma=183$ & $100 \%$ \\
\hline Večernji list & 10 & 5 \\
\hline Jutarnji list & 15 & 8 \\
\hline Novi list & 10 & 5 \\
\hline 24 Sata & 148 & 82 \\
\hline Prava adolescenata & $\Sigma=210$ & $100 \%$ \\
\hline Večernji list & 123 & 59 \\
\hline Jutarnji list & 35 & 16 \\
\hline Novi list & 30 & 15 \\
\hline 24 Sata & 22 & 10 \\
\hline Prava osoba $\mathrm{s}$ invaliditetom & $\Sigma=104$ & $100 \%$ \\
\hline Večernji list & 17 & 14 \\
\hline Jutarnji list & 7 & 8 \\
\hline Novi list & 8 & 9 \\
\hline 24 Sata & 72 & 69 \\
\hline \multicolumn{3}{|l|}{ Bioetika i medicina } \\
\hline Potpomognuta oplodnja & $\Sigma=43$ & $100 \%$ \\
\hline Večernji list & 29 & 68 \\
\hline Jutarnji list & 5 & 11 \\
\hline Novi list & 5 & 11 \\
\hline 24 Sata & 4 & 10 \\
\hline Pobačaj & $\Sigma=\mathbf{3 7}$ & $100 \%$ \\
\hline Večernji list & 4 & 11 \\
\hline Jutarnji list & 11 & 30 \\
\hline Novi list & 17 & 46 \\
\hline 24 Sata & 5 & 13 \\
\hline Eutanazija & $\Sigma=36$ & $100 \%$ \\
\hline Večernji list & 19 & 53 \\
\hline Jutarnji list & 9 & 25 \\
\hline
\end{tabular}




\begin{tabular}{|c|c|c|}
\hline Novi list & 4 & 1 \\
\hline 24 Sata & 4 & 1 \\
\hline Farmakologija i lijekovi & $\Sigma=115$ & $100 \%$ \\
\hline Večernji list & 14 & 12 \\
\hline Jutarnji list & 39 & 34 \\
\hline Novi list & 37 & 32 \\
\hline 24 Sata & 25 & 22 \\
\hline Presađivanje organa & $\Sigma=53$ & $100 \%$ \\
\hline Večernji list & 16 & 31 \\
\hline Jutarnji list & 7 & 13 \\
\hline Novi list & 11 & 20 \\
\hline 24 Sata & 19 & 36 \\
\hline \multicolumn{3}{|l|}{ Spolnost i ljudsko rađanje } \\
\hline Obitelj & $\Sigma=269$ & $100 \%$ \\
\hline Večernji list & 121 & 45 \\
\hline Jutarnji list & 93 & 35 \\
\hline Novi list & 34 & 13 \\
\hline 24 Sata & 20 & 7 \\
\hline Spolni odgoj & $\Sigma=72$ & $100 \%$ \\
\hline Večernji list & 7 & 10 \\
\hline Jutarnji list & 48 & 67 \\
\hline Novi list & 8 & 11 \\
\hline 24 Sata & 9 & 11 \\
\hline Homoseksualnost & $\Sigma=267$ & $100 \%$ \\
\hline Večernji list & 148 & 55 \\
\hline Jutarnji list & 104 & 39 \\
\hline Novi list & 11 & 4 \\
\hline 24 Sata & 5 & 2 \\
\hline \multicolumn{3}{|c|}{ Društvo, zdravstvo i kvaliteta života } \\
\hline Hrana i GMO & $\Sigma=184$ & $100 \%$ \\
\hline Večernji list & 14 & 8 \\
\hline Jutarnji list & 159 & 86 \\
\hline Novi list & 7 & 4 \\
\hline 24 Sata & 4 & 2 \\
\hline Ekonomija i zdravstvo & $\Sigma=282$ & $100 \%$ \\
\hline Vecernji list & 56 & 21 \\
\hline Jutarnji list & 145 & 51 \\
\hline Novi list & 72 & 25 \\
\hline 24 Sata & 9 & 3 \\
\hline Zdravlje i prevencija & $\Sigma=135$ & $100 \%$ \\
\hline
\end{tabular}




\begin{tabular}{|l|c|c|}
\hline Vecernji list & 15 & 11 \\
\hline Jutarnji list & 98 & 73 \\
\hline Novi list & 7 & 5 \\
\hline 24 Sata & 15 & 11 \\
\hline Samoubojstvo & $\mathbf{\Sigma} \mathbf{1 1 4}$ & $\mathbf{1 0 0 \%}$ \\
\hline Vecernji list & 76 & 67 \\
\hline Jutarnji list & 6 & 5 \\
\hline Novi list & 29 & 25 \\
\hline 24 Sata & 3 & 3 \\
\hline Infekcija HIV-om & $\mathbf{\Sigma}$ & $\mathbf{1 0 0}$ \\
\hline Vecernji list & 27 & 43 \\
\hline Jutarnji list & 12 & 19 \\
\hline Novi list & 20 & 32 \\
\hline 24 Sata & 4 & 6 \\
\hline $\begin{array}{l}\text { Ovisnost (droga, pušenje, alkohol, } \\
\text { doping) }\end{array}$ & $\mathbf{\Sigma}=\mathbf{6 7 2}$ & $\mathbf{1 0 0 \%}$ \\
\hline Vecernji list & 439 & 65 \\
\hline Jutarnji list & 47 & 7 \\
\hline Novi list & 124 & 19 \\
\hline 24 Sata & 62 & 9 \\
\hline $\begin{array}{l}\text { Okoliš (zagađenje, izvori, klima, } \\
\text { životinje, biljke, energetika) }\end{array}$ & $\mathbf{\Sigma}=\mathbf{9 3 0}$ & $\mathbf{1 0 0 \%}$ \\
\hline Vecernji list & 302 & 32 \\
\hline Jutarnji list & 379 & 41 \\
\hline Novi list & 60 & 6 \\
\hline 24 Sata & & \\
\hline
\end{tabular}

Izvor: (Volarić- Mršić, 2017, 95-122)

\section{Literatura:}

Aramini, Michele (2009). Uvod u bioetiku. Zagreb: Kršćanska sadašnjost.

Baggio, Antonio Maria (1996). Il ruolo dei mass media nella formazione della coscienza etica e bioetica. U: Elio Sgreccia, Vincenza Mele i Miranda Gonzalo (ur.), Le radici della Bioetica. Rim: Vita e Pensiero.

Bentivegna, Sara (2008). Teorie delle comunicazioni di massa. Bari: Editori Laterza.

Bertrand, Claude-Jean (2007). Deontologija medija. Zagreb: International Center for Education of Journalists.

Belsey, Andrew; Chadwick Ruth (ur.) (1996). Etica e giornalismo. Torino: SEI Torino.

Benedikt XVI. (2008). I mezzi di comunicazione sociale: al bivio tra protagonismo e servizio: Cercare la verità per condividerla. Cinisello Balsamo: Edizioni Paoline.

Bergoglio, Jorge (2013). Korupcija — zlo našeg vremena. Split: Verbum.

Bickman, Leonard; Rog, Debra J. (1998). Handbook of Applied Social Research Methods. Newsbury Park: Sage. 
Cantoni, Lorenzo; Di Blas, Nicoletta (2002). Teoria e pratiche della comunicazione. Torino: Apogeo.

De Neen, Brown (2016). 'You've got bad blood': The horror of the Tuskegee syphilis experiment. U: The Washington Post. URL: https://www.washingtonpost.com/news/ retropolis/wp/2017/05/16/youve-got-bad-blood-the-horror-of-the-tuskegee-syphilis-experiment/?utm_term =.c6575e8907d1 (20.10.2017.)

Čović, Ante (2004). Etika i bioetika. Zagreb: Pergamena.

Edgar, Andrew (1996). Oggettività, pregiudizi e verità. U: Andrew Belsey i Ruth Chedwick, Etica e giornalismo (str. 165-180). Torino: SEI.

Ferri, Pietro (2007). Bioetica, ambiente, salute. Parma: Monte Università di Parma.

Evans, Martin (1999). Bioethics and Newspapers. The Journal of Medicine and Philosophy, 24, 164-165.

Gelb, Zlatan (2008). Moć slike. Dubrovnik: Medianali.

Labaš, Danijel (ur.) (2011). Komunikacija i mediji u krizi. Zagreb: Hrvatski studiji.

Malović, Stjepan (2005). Osnove novinarstva. Zagreb: Golden marketing - Tehnička knjiga.

Malović, Stjepan; Ricchiardi, Sherry; Vilović, Gordana (2007). Etika novinarstva. Zagreb: ICEJ.

McCombs, M; Reynolds, A (2002). News influence on our pictures of the world. U: Jennings Bryant, Dolf Zillmann (ur.), Media effects: Advances in Theory and Research (str. 1-18). Mahwah — New Jersey — London: Lawrence Erlbaum Associates.

McQuail, Denis (2010). Mass communication Theory. London: Sage.

Muzur, Amir; Rinčić, Iva (2011). Fritz Jahr — the Father of European Bioethics. Synthesis philosophica, 26 (1), 133-135.

Papa Franjo (2015). Laudato si': Enciklika o brizi za zajednički dom. Zagreb: Kršćanska sadašnjost.

Petrini, Carlo (2002). Bioetica, ambiente, rischio. Rim: Logos.

Pozaić, Valentin (ur.) (2004). Ekologija. Zagreb: Centar za bioetiku.

Pozaić, Valentin (1998). Čuvari života. Zagreb: Centar za bioetiku.

Privitera, Salvatore; Vecchio, Giorgio (ur.) (1999). La notizia a confronto con l'etica. Acireale: Istituto siciliano di Bioetica.

Reich, Warren Thomas (ur.) (1978). Encyclopedia of Bioethics. New York: Macmillan Publishers.

Reich, Warren Thomas (ur.) (1995). Encyclopedia of Bioethics. New York: Macmillan Publishers.

Schooyans, Michel (1998). Bioéthique et population: le choix de la vie. Pariz: Librairie Arthème Fayard.

Sgreccia, Elio (1999). Manuale di bioetica. Milano: Vita e Pensiero.

Simonson, Peter (2002). Bioethics and the Rituals of Media. The Hastings Center Report, 32 (1), 32-39. URL: http://onlinelibrary.wiley.com/doi/10.2307/3528295/pdf (20.10.2017.)

Ure, Mariano (2010). Filosofia della comunicazione. Torino: Effatta Ed.

Velázquez, Lourdes (2016). La necesidad de un espacio propio para la bioética en los medios de comunicación. Studia Bioethica, 8 (1), 13-19. URL: https://riviste.upra. org/index.php/bioethica/article/viewFile/835/868 (20.10.2017.)

Vilović, Gordana (2007). Povijest vijesti. Opatija: Sveučilišna biblioteka — ICEJ.

Volarić Mršić, Ana (2009a). Distribucijska pravednost i problem jednake raspodjele resursa u zdravstvu. U: Goran Ivanišević (ur.), Dostupnost medicinskih postupaka $\mathrm{u} \mathrm{Hr}$ - 
vatskoj: Knjiga izlaganja na IX. proljetnom bioetičkom simpoziju Hrvatskog liječničkog zbora, Zagreb, 5. lipnja 2009. (str. 11-27). Zagreb: Hrvatski liječnički zbor.

Volarić Mršić, Ana (2009b). Frequency of Articles on Bioethical Issues in Croatian Daily Newspaper „Vjesnik“. U: Iva Sorta Bilajac (ur.), The challenge of cross-cultural bioethics int he 21th century: a satellite meeting at the 9th World Congress of Bioethics, Rijeka, Croatia, 3-8 September, 2008. (str. 76). Rijeka: ISCB.

Volarić Mršić, Ana (2017). La bioetica e i mass media in Croazia (Doktorski rad). Facoltà di Bioetica, Ateneo Ponitificio Regina Apostolorum, Rim.

Wolf, Mauro (1992). Gli effetti sociali dei media. Milano: Bompiani.

Zagorac, Ivana; Jurić, Hrvoje (2008). Bioetika u Hrvatskoj. Filozofska istraživanja, 28 (3), 601-611.

\section{Bioethics in Croatian Daily Newspapers}

\section{Ana Volarić Mršić*}

\section{Summary}

Multiple scientific papers deal with bioethics and the promotion thereof, so too this article puts forth some perspectives, particularly that of the deontological nature of journalism, in order to enable a systematic and analytical evaluation of the professional merit of texts published in Croatia's most-read daily newspapers. We encounter topics in the press on a daily basis which are typically bioethical, but which are recognized as such only by the alert reader, the reason being that bioethics is a young academic interdisciplinary field, the theory of which must be appreciated in order that the topics it covers may be approached from this angle and presented as being such, namely bioethical. An examination of Večernji list, Jutarnji list, Novi list and 24 Sata through a the period of the first six months of 2014 has indicated that in Croatian journalistic circles bioethics is still unrecognized as an academic field which merits study, as opposed to sports, economics or politics all of which have their particular reporters whom we may rightly consider to be experts in these areas. Perhaps the time is coming for bioethical journalism to be brought to life in Croatia, that it may contribute in a constructive way to the development of contemporary Croatian society, in accordance with all the deontological principles of professional journalism, which is to be credited for the global rise of bioethics to academic levels toward the end of the previous century. This paper presents results qualitatively, that is, it provides qualitative analyses of all texts considered and which have been classified as texts containing bioethical content and which were published between January 1 and July 1, 2014.

Key words: bioethics, journalism, Večernji list, Jutarnji list, Novi list, 24 Sata

* Ana Volarić Mršić, Ph.D., University Department of Croatian Studies, University of Zagreb (external associate). Address: Borongajska cesta 83d, 10000 Zagreb, Croatia. E-mail: avmrsic@ gmail.com 